\title{
PEMETAAN SEBARAN DAERAH RAWAN KEKERINGAN UNTUK MENENTUKAN SISTEM PERTANIAN DI KABUPATEN LOMBOK TENGAH
}

\author{
Muhammad Fauzi', Tuti Mutia², Ramli Akhmad ${ }^{3 *}$, Hasrul Hadi ${ }^{4}$ \\ 1,23,4Program Studi Pendidikan Geografi, Fakultas Ilmu Sosial dan Ekonomi, Universitas Hamzanwadi, Selong, Indonesia \\ *Email Koresponden: perahuimaji@gmail.com
}

Diterima: 16-05-2021, Revisi: 06-06-2021, Disetujui: 26-06-2021

(C)2021 Program Studi Pendidikan Geografi, FISE, Universitas Hamzanwadi

\begin{abstract}
Abstrak Kekeringan merupakan fenomena yang dapat berdampak terhadap berbagai sektor penting seperti sektor pertanian, kehutanan, perkebunan, dan sumberdaya air. Penelitian ini bertujuan untuk memetakan sebaran daerah rawan kekeringan di Kabupaten Lombok Tengah, hal ini sebagai upaya menentukan sistem pertanian yang cocok. Pengumpulan data dilakukan dengan teknik studi dokumen dan observasi. Data dianalisis dengan pendekatan Sistem Informasi Geografis (SIG) yaitu dengan teknik tumpang susun (overlay). Hasil penelitian ini menunjukkan: 1) daerah yang mengalami kekeringan dengan kategori sangat rawan yaitu Kecamatan Praya Tengah; 2) daerah yang mengalami kekeringan dengan kategori rawan yaitu Kecamatan Pujut, Kecamatan Praya Timur, Kecamatan Janapria, Kecamatan Kopang, Kecamatan Batukliang, dan Kecamatan Jonggat; 3) daerah yang mengalami kekeringan dengan kategori sangat tidak rawan yaitu Kecamatan Batukliang Utara, Pringgarata, Praya, Praya Barat Daya, dan Praya Barat; 4) berdasarkan kategori tingkat kerawanan kekeringannya, maka daerah dengan tingkat kekeringan sangat rawan cocok dengan sistem pertanian tegal pekarangan, daerah dengan tingkat kekeringan rawan cocok dengan sistem sawah, dan daerah dengan tingkat kekeringan sangat tidak rawan cocok dengan sistem ladang dan pekarangan.
\end{abstract}

Kata kunci: pemetaan, daerah rawan kekeringan, sistem pertanian

\begin{abstract}
Drought is a phenomenon that can have an impact on various important sectors such as agriculture, forestry, plantations, and water resources. This study aims to maping the distribution of drought-prone areas in Central Lombok. Regency, this is an effort to determine a suitable agricultural system. Data was collected by using document study and observation techniques. The data were analyzed using a Geographic Information System (GIS) approach, namely the overlay technique. The results of this study indicate: 1) areas experiencing drought with a very vulnerable category, namely Praya Tengah District; 2) areas experiencing drought in the vulnerable category, namely Pujut District, East Praya District, Janapria District, Kopang District, Batukliang District, and Jonggat District; 3) areas experiencing drought with a very non-prone category, namely the Districts of Batukliang Utara, Pringgarata, Praya, Praya Barat Daya, and Praya Barat; 4) based on the category of drought susceptibility, areas with very bigh drought susceptibility are suitable for the upland farming system, areas with drought-prone levels are suitable for the paddy field system, and areas with very low drought susceptibility are suitable for the farm and yard system.
\end{abstract}

Keywords: mapping, drought prone areas, agricultural systems

\section{PENDAHULUAN}

Bencana kekeringan merupakan bencana alam yang termasuk dalam kategori bencana hidroklimatologis yang terjadi sebagai imbas dari fenomena ENSO (El nino Southern Oscillation) dan La nina (Hadi, Agustina, \& Subhani, 2019). Kekeringan berhubungan dengan keseimbangan antara kebutuhan dan pasokan air untuk berbagai keperluan. Dampak kekeringan terjadi di berbagai sektor terutama di sektor pertanian, perkebunan, kehutanan, sumberdaya air, dan lingkungan. Kekeringan Sering terjadi di berbagai daerah di Indonesia (Adiningsih, 2014). Khususnya dalam sektor pertanian, bencana kekeringan berdampak terhadap terganggunya sistem irigasi sehingga mengakibatkan produktivitas hasil pertanian mengalami penurunan. Minimnya ketersediaan air akibat bencana 
kekeringan dapat menghambat pertumbuhan produksi pertanian utamanya padi sebagai bahan makanan pokok, yang selanjutnya mempengaruhi perekonomian lokal dan nasional (Saidah, Budianto, \& Hanifah, 2017).

Provinsi Nusa Tenggara Barat menjadi salah satu provinsi di Indonesia yang mayoritas penduduknya bekerja di sektor pertanian. Berdasarkan potensi areal pertanian Nusa Tenggara Barat, luas lahan kering di provinsi NTB seluas $893.758 \mathrm{Ha}$, dan lahan kering yang sudah dimanfaatkan seluas $287.085 \mathrm{Ha}(32 \%)$ (Dinas Pertanian Provinsi NTB, 2019). Angka tersebut menunjukkan potensi lahan kering sangat besar apabila dikelola dengan baik untuk dijadikan lahan pertanian guna meningkatkan hasil produksi pertanian. Salah satu kabupaten di provinsi NTB yang memiliki lahan kering dan berpotensi untuk dikembangkan sektor pertaniannya adalah Kabupaten Lombok Tengah. Berdasarkan data BPS tahun 2014 diketahui bahwa di Kabupaten Lombok Tengah terdapat 69.650 ha lahan kering.

Untuk mengatasi permasalahan bencana kekeringan khususnya pada sektor pertanian, maka dibutuhkan langkah-langkah yang tepat sebagai bentuk adaptasi terhadap terjadinya kekeringan. Adaptasi tersebut erat kaitannya dengan penerapan sistem pertanian yang tepat, khususnya pada lahan yang rawan kekeringan. Oleh sebab itu maka, penting kiranya diketahui daerah mana saja yang berpotensi rawan kekeringan serta sistem pertanian apa yang cocok diterapkan guna melangsungkan kehidupan para petani sebagai bentuk adaptasi atas terjadinya kekeringan. Salah satu cara untuk mengetahui tingkat sebaran kekeringan suatu wilayah yaitu dengan menggunakan pendekatan Sistem Informasi Geografis (SIG) dengan memanfaatkan data penginderaan jauh. Penggunaan data penginderaan jauh, khususnya citra satelit maupun foto udara dinilai cukup efektif memetakan daerah rawan kekeringan, bahkan telah dilakukan sejak tahun 1980-an (Adiningsih, 2014).

Keunggulan menggunakan data penginderaan jauh yaitu salah satunya karena dengan memanfaatan citra satelit maupun citra foto maka dapat mempermudah menggambarkan obyek, daerah, dan gejala di permukaan bumi dengan wujud dan letak obyek yang mirip dengan wujud dan letaknya di permukaan bumi, relatif lengkap, meliputi daerah yang luas, dan permanen (Sutanto, 1994). Penginderaan jauh dalam pengolahan data satelit memberikan pandangan sinoptik permukaan bumi, karena itu dapat digunakan untuk mengevaluasi terjadinya kekeringan secara spasial. Metode dalam mengetahui indeks kekeringan telah dikembangkan dan diterapkan, yang meliputi durasi, intensitas, tingkat keparahan, dan luasnya (Trisasongko et al., 2015).

Selain menggunakan data penginderaan jauh, pendekatan yang penting dilakukan untuk pemetaan sebaran daerah rawan kekeringan yaitu dengan pendekatan Sistem Informasi Geografis (SIG). penggunaan pendekatan SIG penting dilakukan untuk mengatasi hambatan pemetaan sebaran kekeringan atau penyediaan informasi kekeringan secara spasial yang up-to-date atau real time. Sistem Informasi Geografis sebagai salah satu teknologi yang berkembang saat ini dapat digunakan sebagai alat untuk membantu menghasilkan data dan informasi seperti yang dimaksud, dengan menggunakan parameter-parameter tumpang susun (overlay) dengan metode intersect yaitu untuk mengetahui seberapa besar potensi bencana kekeringan lahan pertanian yang berkaitan dengan tema penelitian (Puspitasari, 2017).

Beberapa penelitian sebelumnya menampilkan pentingnya pendekatan spasial berupa pendekatan SIG dan Penginderaan Jauh dalam memetakan daerah rawan kekeringan. Penelitian dari Hasdir (2017) misalnya, yang mengidentifikasi daerah rawan kekeringan berbasis data spasial penginderaan jauh di Kabupaten Soppeng. Hasil penelitiannya menunjukkan kelas kerawanan tinggi, sedang dan rendah berturut-turut terdapat di Kecamatan Marioriawa, Kecamatan Mariawawo, dan Kecamatan Lalabata. Inopianti (2017) melakukan penelitian mengenai pemanfaatan aplikasi SIG dan Penginderaan Jauh untuk pemetaan daerah rawan kekeringan di Kabupaten Sukabumi. Dari hasil penelitiannya diketahui bahwa daerah dengan status rawan meliputi luas 31\% dari luas wilayah. Tersebar di Kabupaten Sukabumi bagian selatan, meliputi Kecamatan Ciemas, Kecamatan Ciracap, dan sekitarnya. Tidak jauh berbeda dengan peneliti sebelumnya, Satriawan (2015) juga melakukan penelitian berkaitan dengan pemanfaatan aplikasi Sistem Informasi Geografi untuk pemetaan daerah rawan kekeringan di Kabupaten Klaten. Ia menyimpulkan bahwa Kabupaten Kelaten memiliki wilayah dengan tingkat kerawanan kekeringan mulai dari tingkat rawan, sedang dan tidak rawan. Daerah dengan status rawan 
meliputi Kemalang, Jatinom, Bayat, Wedi dan Gantiwarno. Namun demikian, secara keseluruhan, Kabupaten Klaten masuk dalam kategori daerah dengan tingkat kerawanan sedang.

Berdasarkan beberapa penelitian yang telah diuraikan, maka diketahui betapa pentingnya melakukan pemetaan daerah rawan kekeringan sebagai langkah awal melakukan mitigasi bencana kekeringan. Jika ditelaah lebih lanjut, beberapa penelitian tersebut sebagian besar menitikberatkan pada pemetaan sebaran daerah dengan potensi rawan kekeringan, namun belum memberikan alternatif penggunaan lahan dengan sistem pertanian yang tepat. Oleh sebab itu dalam penelitian ini, peneliti mencoba memberikan alternatif tambahan, selain lokasi yang berbeda (Kabupaten Lombok Tengah), juga menawarkan jenis sistem pertanian yang cocok dan tepat diterapkan di masing-masing daerah berdasarkan tingkat kerawanan lahan pertaniannya. Dengan demikian, penelitian ini bertujuan untuk memetakan sebaran daerah rawan kekeringan untuk menentukan sistem pertanian di Kabupaten Lombok Tengah.

\section{METODE PENELITIAN}

Penelitian ini merupakan jenis penelitian deskriptif kualitatif, yaitu sebuah metode penelitian yang memanfaatkan data kualitatif dan dijabarkan sejara deskriptif. Jenis penelitian deskriptif kualitatif kerap digunakan untuk menganalisis kejadian, fenomena, atau keadaan secara sosial. Data kualitatif yang dimaksudkan dalam penelitian ini adalah data hasil pengamatan (observasi) dan data dokumen berupa peta dan citra satelit. Dengan demikian teknik pengumpulan data yang dilakukan adalah dengan teknik observasi dan studi dokumen. Teknik observasi dilakukan untuk melihat dan mengamati secara langsung keadaan di lapangan agar penelitian memperoleh gambaran yang lebih jelas tentang permasalahan yang diteliti. Sementara itu, teknik studi dokumen dilakukan untuk mengumpulkan datadata sekunder dari berbagai sumber. Adapun data dokumen yang dibutuhkan yaitu: data luas wilayah Kabupaten Lombok Tengah per kecamatan, data curah hujan per kecamatan di Kabupaten Lombok Tengah, data jenis tanah, data kemiringan lereng, data citra satelit, serta data-data penunjang lainnya yang dianggap relevan.

Data dokumen dianalisis dengan pendekatan Sistem Informasi Geografis (SIG) yaitu dengan teknik tumpang susun (overlay). Overlay adalah kemampuan untuk menempatkan grafis satu peta di atas grafis peta yang lain dan menampilkan hasilnya di layar komputer atau pada plot. Mengumpulkan datadata yang ada di lapangan dan menganalisis dengan ketentuan parameter-parameter yang sudah ditentukan berdasarkan indikator-indikator yang ada (Puspitasari, 2017). Adapun secara lebih terperinci keseluruhan tahapan analisis data dilakukan dengan tahapan-tahapan yang meliputi: 1) menyusun peta curah hujan per kecamatan di Kabupaten Lombok Tengah; 2) menyusun peta kemiringan lereng per kecamatan di Kabupaten Lombok Tengah; 3) menyusun peta jenis tanah di Kabupaten Lombok Tengah; 4) melakukan teknik tumpang susun (overlay) terhadap peta-peta yang telah disusun; 5) melakukan analisis lanjutan berupa sebaran daerah rawan kekeringan dengan indikator tingkat kerawanan kekeringan sangat rawan, rawan, dan sangat tidak rawan; 6) menganalisis kesesuaian/kecocokan penerapan sistem pertanian berdasarkan tingkat kekeringan daerah yang telah ditentukan.

\section{TEMUAN DAN PEMBAHASAN}

\section{Sebaran Daerah Rawan Kekeringan di Kabupaten Lombok Tengah}

Untuk mengetahui sebaran daerah rawan kekeringan di Kabupaten Lombok Tengah, maka terlebih dahulu dilakukan penyusunan peta tematik berupa peta curah hujan per kecamatan di Kabupaten Lombok Tengah, peta kemiringan tanah di Kabupaten Lombok Tengah, dan peta jenis tanah di Kabupaten Lombok Tengah. Untuk lebih jelasnya akan diuraikan sesuai tahapan-tahapan penelitiannya.

\section{Penyusunan Peta Curah Hijan Per Kecamatan di Kabupaten Lombok Tengah}

Penyusunan peta curah hujan di lakukan dengan menggunakan data curah hujan per kecamatan di Kabupaten Lombok Tengah. Data yang digunakan yaitu data curah hujan dari BPS tahun 2018. Data tersebut memuat informasi berupa kecamatan di Kabupaten Lombok Tengah, curah hujan, dan hari hujan. Namun demikian, untuk memudahkan penyusunan, maka data yang digunakan khususnya data 
kecamatan di Kabupaten Lombok Tengah dengan rata-rata curah hujan tahunannya. Sehingga dapat ditampilkan sebagaimana tercantum pada tabel 1 setelah dimodifikasi.

Tabel 1. Data curah hujan tahunan per kecamatan di Kabupaten Lombok Tengah

\begin{tabular}{|c|l|c|}
\hline No & \multicolumn{1}{|c|}{ Kecamatan } & $\begin{array}{c}\text { Curah Hujan } \\
\text { (mm/tahun) }\end{array}$ \\
\hline 1 & Praya Barat & 110.33 \\
\hline 2 & Praya Barat Daya & 123.29 \\
\hline 3 & P u j u t & 84 \\
\hline 4 & Praya Timur & 75.55 \\
\hline 5 & Janapria & 67.17 \\
\hline 6 & K o p a n g & 90.58 \\
\hline 7 & P r a y a & 124.5 \\
\hline 8 & Praya Tengah & 16.92 \\
\hline 9 & Jonggat & 94.5 \\
\hline 10 & Pringgarata & 155.58 \\
\hline 11 & Batukliang & 98.33 \\
\hline 12 & Batukliang Utara & 163 \\
\hline
\end{tabular}

Sumber: BPS Lombok Tengah, 2018.

Berdasarkan data curah hujan pada tabel 1, maka dikatehui bahwa dari 12 kecamatan di Kabupaten Lombok Tengah, Kecamatan Batukliang Utara memiliki curah hujan tahunan tertinggi yaitu sebesar $163 \mathrm{~mm} /$ tahun. Sedangkan kecamatan dengan curah hujan tahunan terendah terdapat di Kecamatan Praya Tengah, yaitu sebesar $16,92 \mathrm{~mm} /$ tahun. Berdasarkan data tersebut juga dapat diketahui mana saja kecamatan yang masuk kategori bulan basah, bulan lembab, dan bulan kering kaitannya dengan kerawanan kekeringan. Kategori ini merupakan klasifikasi menurut Schmidt Ferguson (1951). Klasifikasi tipe iklim menurut Schmidt-Ferguson hanya menggunakan data curah hujan di suatu wilayah dengan memberikan kriteria curah hujan bulanan pada Bulan Basah, Bulan Lembab dan Bulan Kering. Kategori bulan basah menunjukkan intensitas curah hujan yang tinggi di suatu daerah. Bulan lembab menunjukkan intensitas curah hujan sedang, sedangkan bulan kering menunjukkan intensitas curah hujan rendah. Adapun indikator penentuan bulan basah, bulan lembab, dan bulan kering dapat dilakukan dengan melihat besaran curah hujan yang dikembangkan oleh Schmidt-Ferguson sebagaimana dapat dilihat pada tabel 2 .

Tabel 2. Klasifikasi iklim Schmidt-Ferguson berdasarkan intensitas curah hujan

\begin{tabular}{ccc}
\hline No & Kategori & Curah Hujan (mm/tahun) \\
\hline 1 & Bulan Basah & $>100$ \\
\hline 2 & Bulan Lembab & $60-100$ \\
\hline 3 & Bulan Kering & $<60$ \\
\hline Sumber: Lakitan (2002)
\end{tabular}

Berdasarkan data curah hujan per kecamatan sebagaimana ditampilkan pada tabel 1, maka dapat dikatahui kecamatan mana saja yang masuk dalam kategori daerah bulan basah, bulan lembab, dan bulan kering. Berdasarkan data tersebut diketahui bahwa kecamatan yang termasuk daerah dengan kategori bulan basah adalah kecamatan Praya Barat, Praya Barat Daya, Praya, Pringgarata, dan Batukliang Utara. Kecamatan yang masuk dalam kategori daerah bulan lembab adalah kecamatan Pujut, 
Praya Timur, Janapria, Kopang, Jonggat, dan Batukliang. Sedangkan kecamatan yang masuk kategori daerah bulan kering adalah Kecamatan Praya Tengah.

Berdasarkan data tingkat intensitas curah hujan yang diperoleh pada masing-masing kecamatan, maka selanjutnya dapat disusun peta curah hujan per kecamatan di Kabupaten Lombok Tengah, sebagaimana ditampilkan pada Gambar 1.

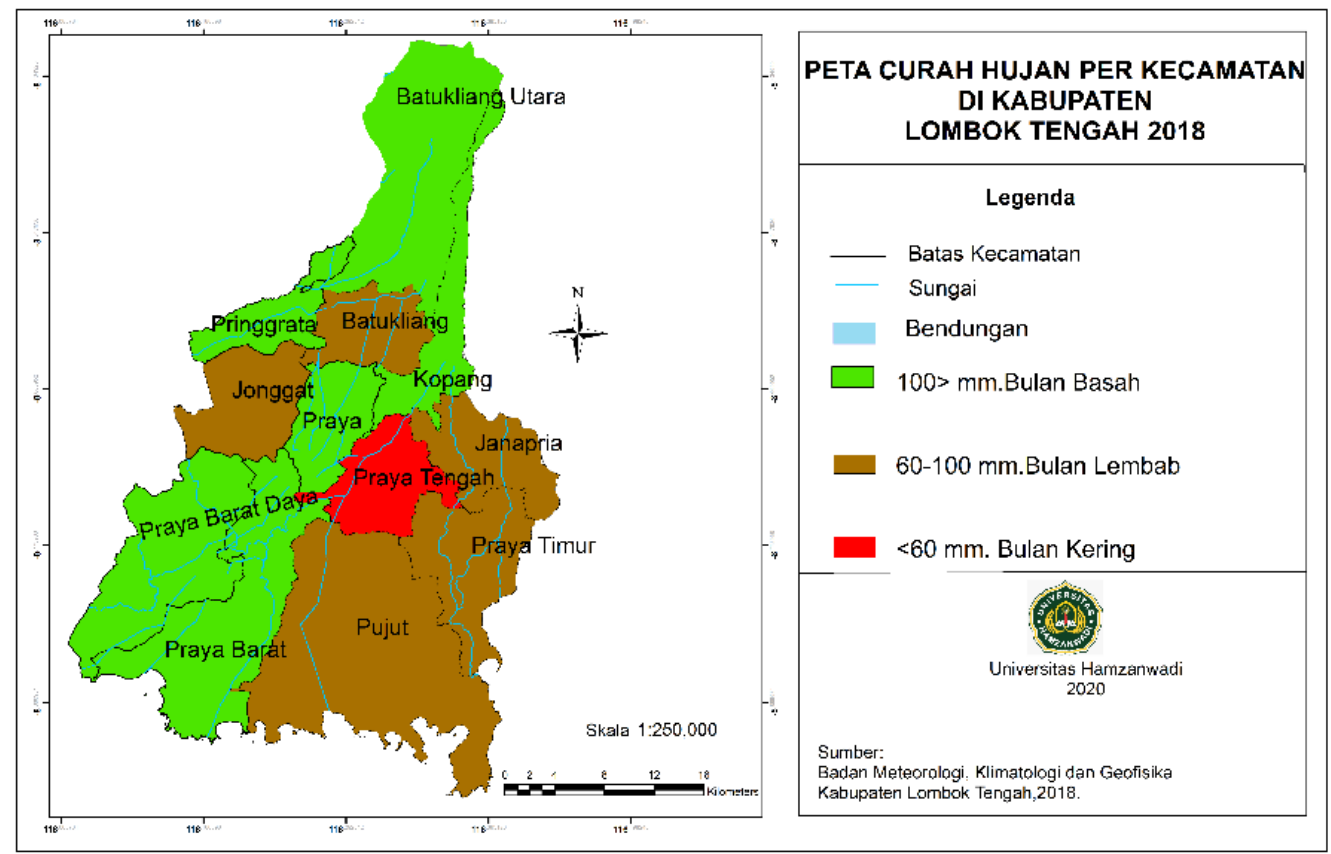

Gambar 1. Peta curah hujan per kecamatan di Kabupaten Lombok Tengah. (Sumber: Peneliti, 2020)

\section{Penyusunan Peta Kemiringan Tanah di Kabupaten Lombok. Tengah}

Bentuk lereng bergantung pada proses penyerapan air dan tampungan air di atas permukaan tanah yang terbagi dalam kemiringan lereng dan beda tinggi relief, dimana kedua bagian tersebut besar pengaruhnya terhadap penilaian suatu lahan kritis. Bentuk kelerengan berpengaruh juga terhadap resapan air tanah, karena akan berdampak pada kekeringan di suatu wilayah. Daerah yang memiliki kelerengan yang tinggi akan berpotensi mengalami kekeringan yang rendah karena penyerapan air yang baik dan biasanya terdapat didaerah pegunungan (Banjarnahor, Hindarto, \& Fahrurrozi, 2018).

Berdasarkan data dari Kementerian Agraria dan Tata Ruang tahun 2019, Kabupaten Lombok Tengah memiliki kemiringan tanah yang dikelompokkan menjadi 4 kelas kemiringan yaitu datar, landai, agak miring, dan sangat miring. Untuk lebih jelasnya dapat dijelaskan sebagai berikut:

1) Kemiringan lereng $0-2 \%$, merupakan daerah datar, umumnya merupakan daerah dataran aluvial sungai, rawa dan pantai. Penyebarannya meliputi seluruh kecamatan di Kabupaten Lombok Tengah dengan luas daerah $\pm 31.142 \mathrm{Ha}$ atau $25,77 \%$ dari luas daerah, dengan luasan terbesar berada di Kecamatan Pujut yaitu seluas $9.733 \mathrm{Ha}$ atau $18,78 \%$ dari luas daerah dengan kemiringan $0-2 \%$.

2) Kemiringan lereng 2 - 15\%, merupakan daerah landai sampai agak miring, umumnya merupakan daerah dataran aluvial sungai. Penyebarannya meliputi seluruh kecamatan di Kabupaten Lombok Tengah dengan luas daerah $\pm 76.179 \mathrm{Ha}$ atau $63.04 \%$ dari luas daerah, dengan luasan terbesar adalah di Kecamatan Pujut yaitu seluas $13.522 \mathrm{Ha}$ atau $17.88 \%$ dari luas daerah dengan kemiringan 2 - 15\%.

3) Kemiringan lereng $15-40 \%$, merupakan daerah agak miring sampai miring, penyebarannya meliputi seluruh kecamatan di Kabupaten Lombok Tengah (kecuali Kecamatan Pujut, Praya Timur, Janapria,Praya, Praya Tengah dan Jonggat) dengan luas daerah $\pm 6.870 \mathrm{Ha}$ atau 5,68\% dari luas daerah, dengan luasan terbesar adalah di Kecamatan Batukliang Utara yaitu seluas $4.336 \mathrm{Ha}$ atau $63,11 \%$ dari luas daerah dengan kemiringan $15-40 \%$.

4) Kemiringan lereng $>40 \%$ merupakan daerah sangat miring sampai curam, penyebarannya meliputi Kecamatan Batukliang dan Batukliang Utara dengan luas daerah $\pm 6.648 \mathrm{Ha}$ atau $5.50 \%$ dari luas 
daerah, dengan luasan terbesar adalah di Kecamatan Batukliang Utara yaitu seluas $5.043 \mathrm{Ha}$ atau $75,85 \%$ dari luas daerah dengan kemiringan $>40 \%$.

Berdasarkan data kemiringan tanah di Kabupaten Lombok Tengah tersebut, maka dapat disusun peta kelas kemiringan tanah di Kabupaten Lombok Tengah. Untuk lebih jelasnya dapat dilihat pada Gambar 2.

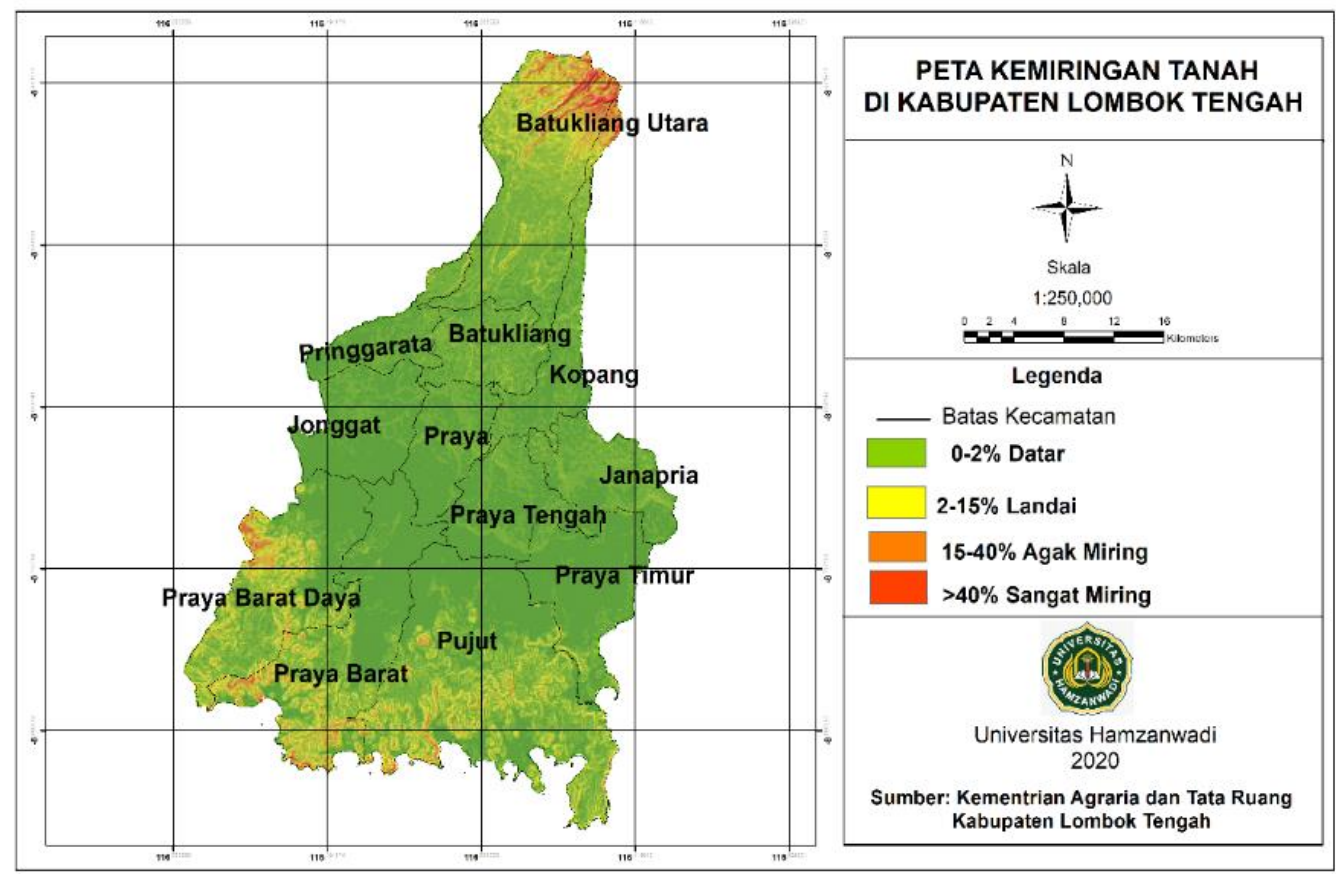

Gambar 2. Peta kemiringan tanah di kabupaten lombok tengah

(Sumber: Peneliti, 2020)

\section{Penyusunan Peta Jenis Tanah di Kabupaten Lombok Tengah}

Untuk mendukung penentuan sistem pertanian yang tepat pada daerah rawan kekeringan, maka penting untuk mengetahui jenis, ciri-ciri dan manfaat tanah yang terdapat pada daerah tersebut. Secara konseptual jenis, ciri-ciri dan manfaat tanah dapat dilihat pada Tabel 3.

Tabel 3. Jenis, ciri-ciri dan manfaat tanah

\begin{tabular}{|c|c|c|c|}
\hline No & Jenis tanah & Ciri-ciri & Manfaat \\
\hline 1 & Aluvial & $\begin{array}{c}\text { Teksturnya lembut mengandung pasir yang } \\
\text { mudah menyerap air dan kaya akan kandungan } \\
\text { mineral. }\end{array}$ & Bertani, berkebun dan bercocok tanam. \\
\hline 2 & Regosol Kelabu & $\begin{array}{c}\text { Mempunyai tekstur tanah yang kasar, butiran- } \\
\text { butiran kasar, mempunyai sifat peka terhadap } \\
\text { erosi tanah, berwarna keabuan, kaya unsur hara, } \\
\text { cenderung gambur, mempunyai kemampuan } \\
\text { menyerap air sangat tinggi, serta mudah terkena } \\
\text { erosi. }\end{array}$ & $\begin{array}{l}\text { Cocok untuk jenis tanaman, padi, kelapa, } \\
\text { tembakau, tebu, dan sayur- sayuran. }\end{array}$ \\
\hline 3 & Regosol Coklat & $\begin{array}{c}\text { Merupakan tanah dari erupsi gunung berapiBelum } \\
\text { menampakan adanya perlapisan horizontal, } \\
\text { memeiliki butiran kasar, berwarna bervariasi dari } \\
\text { merah kuning, coklat kemerahan, dan coklat } \\
\text { kekuningan. }\end{array}$ & $\begin{array}{l}\text { Cocok untuk jenis tanaman, padi, kelapa, } \\
\text { tembakau, tebu, dan sayur- sayuran. }\end{array}$ \\
\hline 4 & $\begin{array}{c}\text { Brown Forest } \\
\text { Soil }\end{array}$ & $\begin{array}{l}\text { Bersifat menyuburkan tanah, terbentuk ribuan } \\
\text { tahun untuk terbentuknya yang biasanya tersebar } \\
\text { di hutan belantara yang berwarna coklat. }\end{array}$ & $\begin{array}{c}\text { Memperbaiki struktur tanah, sebagai } \\
\text { media persemaian cocok untuk ayur- } \\
\text { sayuran. }\end{array}$ \\
\hline 5 & $\begin{array}{l}\text { Gromosol } \\
\text { Kelabu Tua }\end{array}$ & $\begin{array}{l}\text { Kandungan organik rendah, memiliki warna } \\
\text { kelabu hingga hitam, tidak memiliki horizon } \\
\text { eluviasi dan iluviasi, struktur lapisan atas dan } \\
\text { bawah sangat berbeda. }\end{array}$ & $\begin{array}{l}\text { Kurang baik untuk pertanian, namun } \\
\text { apabila didukung dengan irigasi yang baik } \\
\text { maka tanah ini sangat bagus untuk } \\
\text { dikelola sebagai pertanian. }\end{array}$ \\
\hline 6 & Komplek & Merupakan jenis tanah yang kompleks tanah ini & Sangat baik untuk pertanian di daerah \\
\hline
\end{tabular}


Gromosol berskisar antara merah sampai kecoklatan dan

Kelabu Tua,

Mediterian

Coklat Latosol

$7 \quad$ Komplek

Mediterian

Coklat,

Gromosol

Kelabu, Regosol

Coklat Dan

Litosol kapur dari pada jenis tanah kapur yang lainya.

Jenis tanah ini cocok untuk pertanian, namun diimbangi dengan irigasi yang baik dan perawatan tanah yang secara berkala untuk menambah kandungan organiknya.

Sumber: diolah dari berbagai sumber, 2020.

Data yang dari Kementerian Agraria dan Tata Ruang tahun 2019 menunjukkan bahwa di terdapat berbagai jenis tanah berdasarkan luas dan persentasenya. Hal ini dapat dilihat sebagaimana ditampilkan pada Tabel 4.

Tabel 4. Jenis tanah di Kabupaten Lombok Tengah berdasarkan luas area

\begin{tabular}{|c|c|c|c|}
\hline No & Jenis Tanah & Luas (Ha) & Persentase $(\%)$ \\
\hline 1 & Aluvial & 2.414 & 2,01 \\
\hline 2 & Regosol Kelabu & 26.416 & 21,86 \\
\hline 3 & Regosol Coklat & 7.222 & 5,98 \\
\hline 4 & Brown Forest Soil & 9.150 & 7,57 \\
\hline 5 & Gromosol Kelabu Tua & 30.771 & 25,46 \\
\hline 6 & $\begin{array}{l}\text { Komplek Gromosol Kelabu Tua, } \\
\text { Mediterian Coklat Latosol }\end{array}$ & 6.494 & 5,37 \\
\hline 7 & $\begin{array}{l}\text { Komplek Mediterian Coklat, } \\
\text { Gromosol Kelabu, Regosol Coklat } \\
\text { Dan Litosol }\end{array}$ & 38.372 & 31,75 \\
\hline & Total & 120.839 & 100,00 \\
\hline
\end{tabular}

Sumber: Kementerian Agraria dan Tata Ruang, 2019.

Berdasarkan konsep dan data mengenai jenis tanah di Kabupaten Lombok Tengah, maka dapat disusun peta jenis tanah sebagaimana dapat dilihat pada Gambar 3.

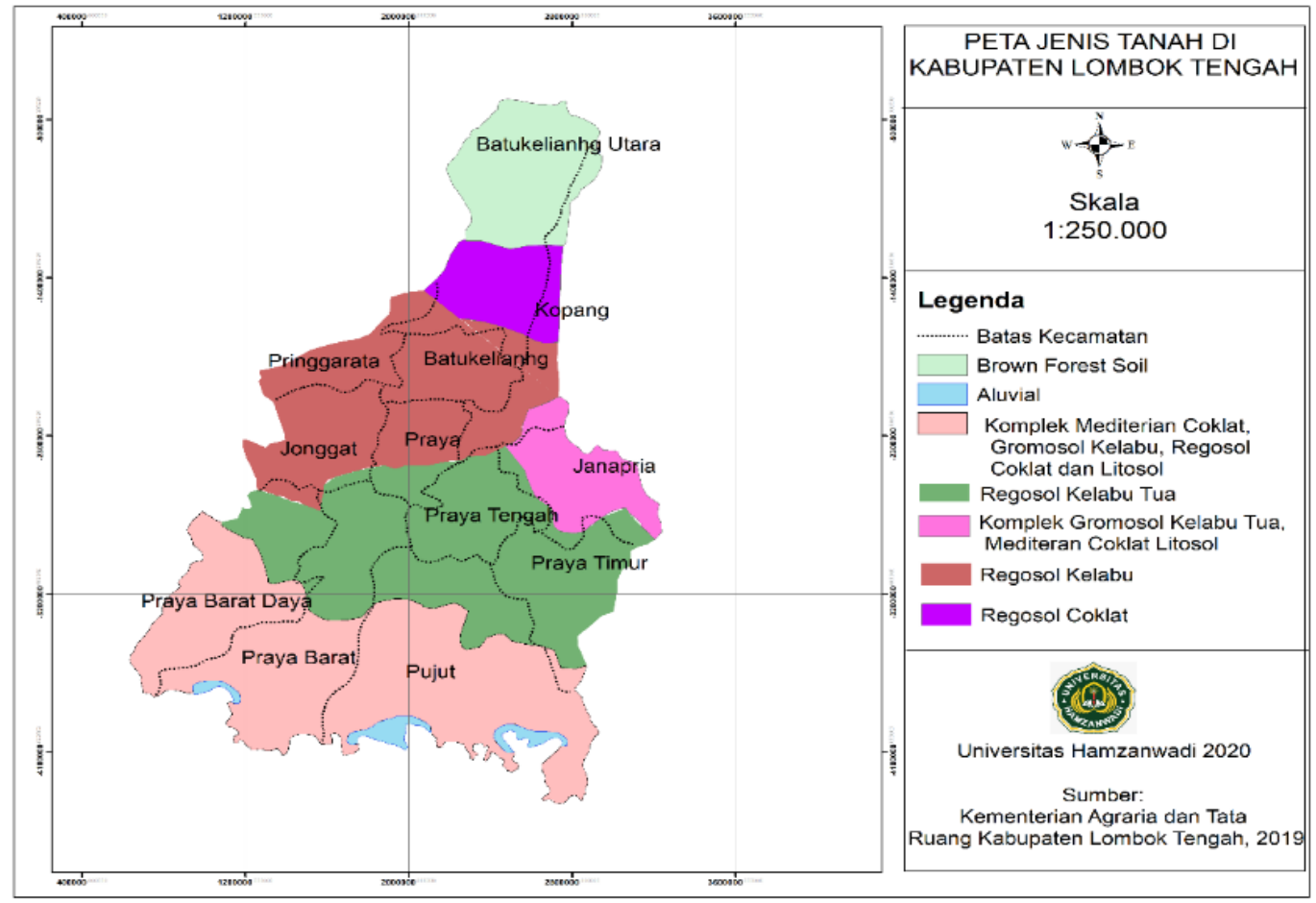

Gambar 3. Peta Jenis Tanah di Kabupaten Lombok Tengah

(Sumber: Peneliti, 2020) 
Berdasarkan konsep jenis tanah dan karakteristiknya, maka diketahui bahwa kekeringan akan lebih berpotensi pada lahan pertanian yang berada pada tanah berjenis aluvial kelabu, aluvial coklat, regosol kelabu, dan mediterian coklat. Dilihat dari sifatnya, jenis tanah tersebut memiliki tekstur tanah yang liat atau liat berpasir, mempunyai konsitensi keras waktu kering dan kompak pada waktu lembab, hal ini akan menyebabkan potensi kekeringan parah pada lahan pertanian (Munir, Sasmito, \& Haniah, 2015).

\section{Kesesuaian Sistem Pertanian pada Daerah Rawan Kekeringan di Kabupaten Lombok Tengah}

Widodo (2014) menjelaskan bahwa terdapat 4 jenis sistem pertanian di Indonesia, yaitu:

1) Sistem Ladang

Sistem Ladang adalah sistem pertanian tingkat rendah atau yang paling primitif. Sistem pertanian ini merupakan sistem peralihan dari mulai tahap budaya pengumpulan ke tahapan budaya penanaman. Pada sistem ini pengolahan tanahnya masih sangat minim dan hasil atau produktivitas sangat bergantung pada hasil atau ketersediaan lapisan-lapisan humus yang ada dalam sistem dan siklus hutan. Pada umumnya sistem ini ditemukan pada daerah-daerah yang memiliki penduduk sedikit dan dengan adanya lahan yang tidak terbatas. Tanaman yang biasa ditanam adalah tanaman pangan, seperti padi, umbi-umbian, jagung dan lainnya;

2) Sistem Tegal Pekarangan

Sistem pertanian ini merupakan sistem yang dikembangkan pada lahan-lahan kering, yang jauh dari sumber-sumber air yang cukup. Pengelolaan tegal sangat jarang menggunakan tenaga intensif dan jarang yang menggunakan tenaga hewan dalam pelaksanaannya. Sistem ini biasa dilakukan para petani apabila mereka telah menetap lama dalam suatu wilayah, meskipun demikian tetap saja tingkat rendah. Tanaman yang biasa diusahakan adalah tanaman-tanaman yang mampu bertahan pada kekeringan, seperti pohon-pohonan;

3) Sistem Sawah

Sistem pertanian ini merupakan suatu sistem atau teknik budidaya tingkat tinggi, dalam hal pengolahan tanah dan pengelolaan sumber air, sehingga mampu mencapai stabilitas biologi yang tinggi dan kesuburan tanah dapat dipertahankan. Sistem sawah adalah sistem yang menghasilkan potensi besar untuk produksi tanaman pangan, baik dalam pengolahan sawah padi ataupun untuk tanaman palawija; dan

4) Sistem Perkebunan

Sistem pertanian yang terakhir ini merupakan sistem pertanian yang dapat digunakan untuk kebutuhan ekspor. Perkebunan rakyat maupun perkebunan besar (estate) semuanya diusahakan tanaman yang memiliki nilai jual tinggi, seperti tanaman karet, kopi, teh dan coklat yang merupakan hasil utama dan sampai sekarang sistem perkebunan berkembang baik dengan menggunakan manajemen industri pertanian.

Berdasarkan ke empat jenis sistem pertanian tersebut maka diketahui jenis tanaman dan manajemen atau pengelolaan pertanian yang dapat dilakukan. Sehingga tentu akan sangat bergantung pada kondisi intensitas curah hujan, kemiringan lahan, serta jenis tanah di suatu daerah. Dengan demikian maka dapat ditentukan sistem pertanian apa yang sekiranya sesuai atau cocok dengan kondisi daerah tersebut. Berdasarkan hasil analisis Sistem Informasi Geografis (SIG) dengan teknik tumpang susun (overlay), maka diketahui bahwa di Kabupaten Lombok Tengah terdapat daerah dengan tiga jenis tingkat kerawanan kekeringan. Berdasarkan tingkat kerawanan tersebut kemudian dapat ditentukan sistem pertanian yang sesuai. yang berbedadan sistem pertanian cocok untuk diterapkan pada lahan kering dengan menggunakan 3 kategori yang terdiri dari:

Tabel 5. Tingkat kerawanan Kekeringan di Kabupaten Lombok Tengah dan sistem pertanian yang sesuai

\begin{tabular}{lll}
\hline Kategori & Sistem Pertanian & Daerah Sebaran/Kecamatan \\
\hline Sangat Rawan & Sistem Tegal Pekarangan. & Praya Tengah \\
\hline Rawan & Sistem Sawah & $\begin{array}{l}\text { Janapria, Praya Timur, Pujut, Jonggat. Batukliang, dan } \\
\text { Kopang. }\end{array}$ \\
\hline \multirow{2}{*}{ Sangat Tidak Rawan } & $\begin{array}{l}\text { Sistem Ladang dan } \\
\text { Sistem Perkebunan. }\end{array}$ & $\begin{array}{l}\text { Praya Barat Daya, Paya Barat, Batukliang Utara, } \\
\text { Kopang, Praya, dan Pringgarata. }\end{array}$ \\
\hline
\end{tabular}

Sumber: Analisis Peneliti, 2020. 
Berdasarkan informasi hasil analisis sebagaimana ditampilkan pada 5 maka selanjutnya dapat dijadikan acuan untuk menyusun peta sebaran daerah rawan kekeringan serta sistem pertanian yang cocok untuk diterapkan. Sehingga, berdasarkan hasil analisis tersebut diperoleh peta sebaran daerah rawan kekeringan dan sistem pertanian di Kabupaten Lombok Tengah, sebagaimana dapat dilihat pada Gambar 4.

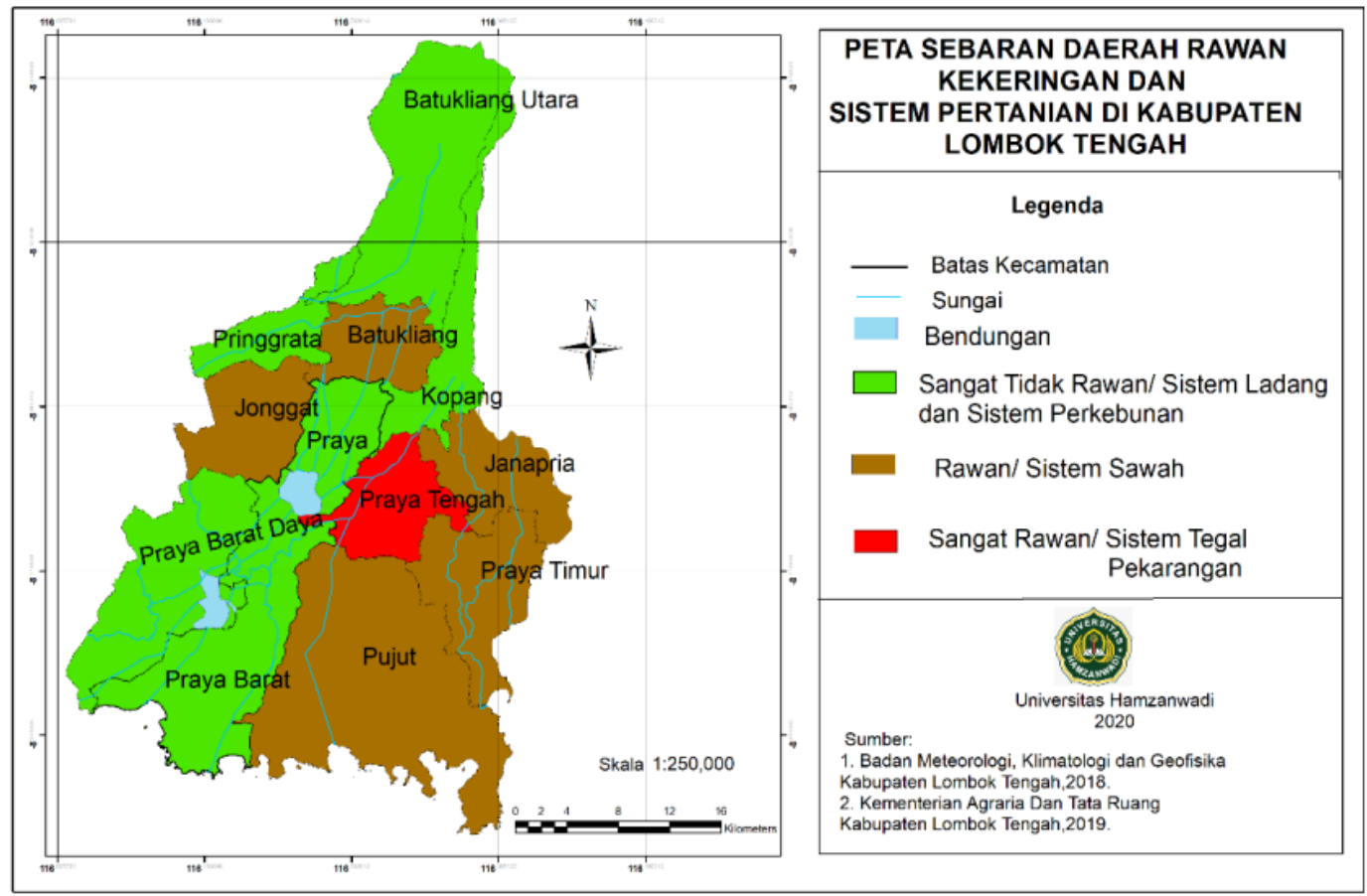

Gambar 4. Peta Sebaran Daerah Rawan Kekeringan dan Sistem Pertanian di Kabupaten Lombok Tengah (Sumber : Hasil Analisis Peneliti, 2020)

\section{SIMPULAN}

Berdasarkan temuan penelitian dan pembahasan maka dapat diperoleh kesimpulan penelitian bahwa Kabupaten Lombok Tengah termasuk daerah dengan tiga jenis tingkat kerawanan kekeringan, yaitu: 1) daerah yang mengalami kekeringan dengan kategori sangat rawan adalah Kecamatan Praya Tengah; 2) daerah yang mengalami kekeringan dengan kategori rawan yaitu Kecamatan Pujut, Kecamatan Praya Timur, Kecamatan Janapria, Kecamatan Kopang, Kecamatan Batukliang, dan Kecamatan Jonggat; 3) daerah yang mengalami kekeringan dengan kategori sangat tidak rawan yaitu Kecamatan Batukliang Utara, Pringgarata, Praya, Praya Barat Daya, dan Praya Barat; 4) berdasarkan kategori tingkat kerawanan kekeringannya, maka daerah dengan tingkat kekeringan sangat rawan cocok dengan sistem pertanian tegal pekarangan, daerah dengan tingkat kekeringan rawan cocok dengan sistem sawah, dan daerah dengan tingkat kekeringan sangat tidak rawan cocok dengan sistem ladang dan pekarangan.

\section{DAFTAR PUSTAKA}

Adiningsih, E. S. (2014). Tinjauan Metode Deteksi Parameter Kekeringan Berbasis Data Penginderaan Jauh. In Seminar Nasional Penginderaan Jauh (211-220).

Banjarnahor, N., Hindarto, K. S., \& Fahrurrozi, F. (2018). Hubungan Kelerengan dengan Kadar Air Tanah, PH Tanah, dan Penampilan Jeruk Gerga di Kabupaten Lebong. Jurnal Ilmu-Ilmu Pertanian Indonesia, 20(1), 13-18.

BPS Kabupaten Lombok Tengah. (2018). Lombok Tengah dalam Angka 2018. Praya: BPS.

Dinas Pertanian Provinsi Nusa Tenggara Barat. (2019). Potensi Investasi Usaba Agribisnis Tanaman Pangan dan Hortikultura Provinsi Nusa Tenggara Barat. Dinas Pertanian Provinsi Nusa Tenggara Barat. 
Hadi, H., Agustina, S., \& Subhani, A. (2019). Penguatan Kesiapsiagaan Stakeholder dalam Pengurangan Risiko Bencana Alam Gempabumi. Geodika: Jumal Kajian Ilmu dan Pendidikan Geografi, 3(1), 30-40.

Hasdir, M. (2017). Identifikasi Daerah Rawan Kekeringan Berbasis Data Spasial Penginderaan Jauh di Kabupaten Soppeng. Makasar: Departemen Ilmu Tanah Fakultas Pertanian Universitas Hasanuddin Makasar.

Inopianti, N. (2017). Pemanfaatan Aplikasi Sistem Informasi Geografis (SIG) dan Penginderaan Jauh untuk Pemetaan Daerah Rawan Kekeringan di Kabupaten Sukabumi. Skripsi. Jakarta: Fakultas Ilmu Tarbiyah dan Keguruan UIN Syarif Hidayatullah Jakarta.

Lakitan, B. (2002). Dasar-Dasar Klimatologi. Jakarta: PT. Raja Grafindo Persada.

Munir, M. M., Sasmito, B., \& Haniah, H. (2015). Analisis Pola Kekeringan Lahan Pertanian di Kabupaten Kendal dengan menggunakan Algoritma Thermal Vegetation Index dari Citra Satelit Modis Terra. Jurnal Geodesi Undip, 4(4), 174-180.

Puspitasari, L. (2017). Analisis Tingkat Rawan Kekekringan Lahan Pertanian Menggunakan Sistem Informasi Geografi di Kabupaten Bantul Tahun 2016. Skripsi. Surakarta: Universitas Muhammadiyah Surakarta.

Saidah, H., Budianto, M. B., \& Hanifah, L. (2017). Analisa Indeks dan Sebaran Kekeringan menggunakan Metode Standardized Precipitation Index (SPI) dan Geographical Information System (GIS) Untuk Pulau Lombok. Jurnal Spektran, 5(2), 173-179.

Satriawan, H. (2015). Aplikasi Sistem Informasi Geografi Untuk Pemetaan Daerah Rawan Kekeringan di Kabupaten Klaten (Doctoral dissertation, Universitas Gadjah Mada).

Sutanto. (1994). Penginderaan Jauh Jilid 1. Yogyakarta: UGM Press.

Trisasongko, B. H., Panuju, D. R., Shiddiq, D., La Ode, S. I., Sholihah, R. I., \& Kusdaryanto, S. (2015). Constraints of VSWI in the Estimation of Drought Extent using Landsat data: A case of Tuban, Indonesia. Procedia Environmental Sciences, 24, 25-28.

Widodo, W. D. (2014). Sistem Pertanian; Dasar-Dasar Budi Daya Tanaman. Jakarta: Penerbit Universitas Terbuka. 